\title{
Kronisk lymfatisk leukemi i Norge - insidens og prognose ved diagnosetidspunktet
}

Engelsk oversettelse på www.tidsskriftet.no

\begin{abstract}
Sammendrag
Bakgrunn. Sykdomsforløpene ved kronisk lymfatisk leukemi (KLL) er svært heterogene. Biologiske markører med god prognostisk utsagnskraft ved diagnosetidspunktet er tilgjengelig. Hensikten med studien var å kartlegge forekomsten av disse markørene i et populasjonsbasert materiale.
\end{abstract}

Materiale og metode. Biologiske markører ble undersøkt med standard laboratoriemetoder etter informert samtykke hos pasienter diagnostisert med kronisk lymfatisk leukemi i perioden 1.10. 2007-31.12. 2009.

Resultater. Det var 388 nye tilfeller av kronisk lymfatisk leukemi i studieperioden, og 236 pasienter (61\%) ble inkludert i studien. Av 222 pasienter var $178(80 \%)$ i Binets stadium A, 26 $(12 \%)$ i stadium B og $18(8 \%)$ i stadium C. $\mathrm{V}_{\mathrm{H}}$-genet var mutert hos $69 \%$ og umutert hos $31 \%$. Cytogenetiske aberrasjoner ble funnet hos $68 \%$ del(13q14) hos $48 \%$, trisomi 12 hos $13 \%$, del(11q22) hos $10 \%$ og del(17p13) hos $7 \%$. CD38-positiv sykdom ble funnet hos $28 \%$ av pasientene. $\mathrm{V}_{\mathrm{H}^{-}}$-genet var mutert hos $67 \%$ av pasientene i Binets stadium $A$, og mutert $V_{H^{-}}$gen var hos flertallet av disse assosiert med manglende ekspresjon av CD38 og del(13q14).

Fortolkning. Ved diagnosetidspunktet er de fleste pasientene asymptomatiske og trenger ikke behandling. De biologiske markørene som indikerer god prognose, forekommer hyppigst i denne gruppen. Markører som indikerer dårlig prognose, forekommer hyppigere i gruppen som har symptomer på diagnosetidspunktet.

\section{Geir E. Tjønnfjord}

geir.tjonnfjord@oslo-universitetssykehus.no Avdeling for blodsykdommer

Oslo universitetssykehus

og

Institutt for klinisk medisin

Universitetet i Oslo

\section{Bernt E. Ly}

Tom Børge Johannesen

Kreftregisteret

\section{Anne Tierens}

Klaus Beiske

Avdeling for patologi

Oslo universitetssykehus

\section{Sverre Heim}

Seksjon for kreftcytogenetikk

Institutt for medisinsk informatikk

Oslo universitetssykehus

og

Institutt for klinisk medisin

Universitetet i Oslo

\section{Viggo Jønsson}

Avdeling for blodsykdommer

Oslo universitetssykehus

og

Institutt for klinisk medisin

Universitetet i Oslo

Kronisk lymfatisk leukemi (KLL) er den hyppigste formen for leukemi $\mathrm{i}$ vår del av verden. I en norsk studie fra siste halvdel av 1990-årene ble det antydet en insidens på nærmere 4/100 000 innbyggere/år og en mann-kvinne-ratio på 1,5 , at median alder ved diagnosetidspunktet var 72 år og at $78 \%$ av pasientene var asymptomatiske da (1). De kliniske forløpene ved kronisk lymfatisk leukemi er svært variable. Ytterpunktene er raskt progredierende sykdom som svarer dårlig på behandling og fører til døden i løpet av $2-3$ år (5-10\% av pasientene) og indolent sykdom som aldri blir behandlingstrengende og unntaksvis går i spontan remisjon $(2,3)$.

Sykdomsstadium er en god variabel for sykdomsutbredelse og har prognostisk utsagnskraft på gruppenivå, men det har vist seg at det er lite egnet til å vurdere prognose på individnivå hos asymptomatiske pasienter. I løpet av de siste ti år har vi fått betydelig innsikt i patofysiologiske forhold, og flere biologiske markører har vist god prognostisk utsagnskraft hos enkeltpasienter ved diagnosetidspunktet. De best etablerte prognostiske markørene er mutasjonsstatus for genet som koder for den variable delen av immunglobulinets tunge kjede, $\mathrm{V}_{\mathrm{H}}$-genet, som KLL-cellene bruker, cytogenetiske aberrasjoner og ekspresjon av CD38 på celleover- flaten (ramme 1) (4-7). Målet for den aktuelle studien var å kartlegge forekomsten av disse markørene ved diagnosetidspunktet $i$ et uselektert norsk pasientmateriale.

\section{Materiale og metode \\ Pasientpopulasjon}

Alle som ble diagnostisert med kronisk lymfatisk leukemi i perioden 1.10. 2007-31.12. 2009, ble invitert til å delta i studien. Pasientene ble informert om studien av behandlingsansvarlig lege og ble inkludert etter informert skriftlig samtykke. De etterspurte pasientdataene ble, sammen med ordinær kreftmelding, sendt til Kreftregisteret, som fungerte som sekretariat for studien. I de tilfellene Kreftregisteret mottok melding om et nytt tilfelle av kronisk lymfatisk leukemi uten at pasienten var inkludert i studien, ble legen som hadde sendt kreftmeldingen tilskrevet med anmodning om å forespørre pasienten om inklusjon. All kontakt med pasientene skjedde gjennom behandlingsansvarlig lege.

Studien var et samarbeidsprosjekt mellom Norsk selskap for hematologi og Kreftregisteret. Norske hematologer ble orientert om studien gjennom Norsk selskap for hematologi, og detaljert informasjon om studien var tilgjengelig på selskapets og på Kreftregisterets hjemmesider.

Studien var godkjent av regional komité for medisinsk forskningsetikk (REK S-06353b) og Datatilsynet (07/00254-2).

\section{Diagnostiske kriterier}

For å stille diagnosen kronisk lymfatisk leukemi var det nødvendig å dokumentere vedvarende klonal B-lymfocytose $\left(\geq 5 \cdot 10^{9} / 1\right)$

\section{Hovedbudskap}

- De fleste pasienter med kronisk lymfatisk leukemi er asymptomatiske ved diagnosetidspunktet og skal ikke behandles

- De fleste asymptomatiske pasientene har en profil av biologiske markører som indikerer god prognose

- To tredeler av pasientene har cytogenetiske aberrasjoner ved diagnosetidspunktet

- Det foretrukne $\mathrm{V}_{\mathrm{H}^{-}}$-gen er mutert hos $69 \%$ av pasientene ved diagnosetidspunktet 
med en karakteristisk immunfenotype i henhold til internasjonale retningslinjer (8). Småcellet lymfocyttært lymfom (SLL) skiller seg kun fra kronisk lymfatisk leukemi ved fravær av leukemisk fenotype. Pasienter med klonal B-lymfocytose, men $<5 \cdot 10^{9} / 1$, lymfeknutesvulst og/eller splenomegali og karakteristiske histologiske funn i lymfeknute og/eller beinmarg ble inkludert under diagnosen småcellet lymfocyttært lymfom.

Sykdomsstadium ble bedømt etter Binets stadieinndeling (9). Den er basert på klinisk undersøkelse og bestemmelse av hemoglobin- og trombocyttnivå (tab 1).

\section{Væskestrømscytometri}

Immunfenotyping ble gjort ved hjelp av væskestrømscytometri. Firefargeanalyse av lymfocytter i blod ble utført etter merking med antistoffer, lysering av erytrocytter og cellevask, som tidligere beskrevet (10). Prosentandelen CD38-positive KLL-celler ble estimert ut fra fluorescens i den aktuelle prøven minus fluorescens i kontrollprøven. CD38-positivitet ble definert som $\geq 20 \%$ positive KLL-celler.

\section{Molekylærgenetikk}

Genet som kodet for den variable delen av immunglobulinets tunge kjede $\left(\mathrm{V}_{\mathrm{H}}\right.$-genet $) \mathrm{i}$ KLL-cellene ble identifisert ved sekvensering, og genets mutasjonsstatus ble undersøkt med DNA-basert teknikk $(11,12) . \mathrm{V}_{\mathrm{H}^{-}}$ genet ble karakterisert som umutert ved $\geq 98 \%$ homologi med kimbanen og som mutert ved $<98 \%$ homologi med kimbanen $(4,5)$. Det ble brukt genomisk polymerasekjedereaksjon (PCR) for amplifisering av det rearrangerte $\mathrm{V}_{\mathrm{H}}$-genet.

\section{Cytogenetikk}

Forekomst av cytogenetiske avvik ble undersøkt ved karyotypering av korttidsdyrkede beinmargsceller (G-banding av kromosomer i metafase) og/eller ved interfase fluorescerende in situ-hybridiserings (FISH)undersøkelse av blod-eller beinmargsceller etter standardmetoder. FISH-resultatene ble klassifisert som ingen cytogenetiske aberrasjoner, trisomi 12, del(6q23), del(11q22), del(13q14) eller del(17p13) som eneste avvik eller i kombinasjoner (to eller flere avvik funnet hos samme pasient).

\section{Statistiske metoder}

Det er benyttet deskriptiv statistikk med angivelse av median, gjennomsnitt, spredning og ratio. Khikvadrattest ble benyttet for å vise samvariasjon mellom biologiske markører. Aldersjustert insidens ble beregnet ut fra standardbefolkningen i USA i år 2000 fordi vi ikke hadde data fra noen norsk befolkning.

\section{Resultater}

Pasientene

I studieperioden ble det meldt 388 nye tilfeller av kronisk lymfatisk leukemi til Kreftregisteret. Dette gir en insidens på 3,6/100 000/år
(4,8 millioner innbyggere i Norge 2009-10). Det tilsvarer en aldersjustert insidens på 3,8/ 100 000/år. 236 av disse pasientene $(61 \%)$ ble inkludert i studien, hvorav åtte ble rubrisert under småcellet lymfocyttært lymfom. Av de inkluderte var det 139 menn og 97 kvinner, det vil si en mann-kvinne-ratio på 1,43.

Stadieinndelingen fremgår av tabell 2. Gjennomsnittsalder ved diagnosetidspunktet var 65,9 år (median 65,0 år). Alderen hos dem som ikke ble inkludert i studien, var gjennomgående høyere - gjennomsnittsalder 72,1 år (median 73,0 år) - og det var en mann-kvinneratio på 1,66. I tråd med at majoriteten av pasientene var i stadium A var gjennomsnittsverdiene for hemoglobin $13,5 \mathrm{~g} / 100 \mathrm{ml}$ (median 13,9 g/100 ml; spredning 5,1-17,5 g/ $100 \mathrm{ml}$ ), lymfocytter $31 \cdot 10^{9} / 1 \quad$ (median $16,5 \cdot 10^{9} / 1$, spredning $\left.1,4-232 \cdot 10^{9} / 1\right)$ og trombocytter $210 \cdot 10^{9} / 1$ (median $211 \cdot 10^{9} / 1$, spredning $\left.29-432 \cdot 10^{9} / 1\right)$.

\section{Immunfenotyping}

Hos 228 pasienter (97\%) var den væskestrømscytometriske undersøkelsen fullstendig nok til at KLL-skår etter Matutes og medarbeidere kunne angis (den går fra 0 til 5) (13). Maksimal skår er 5 (skår $5=$ alternativ diagnose usannsynlig, skår 0 = alternativ diagnose sannsynlig). Det var 192 pasienter med skår 5, 25 med skår 4, ni med skår 3 og to med skår 2. CD38-ekspresjon kunne vurderes hos 211 pasienter - 59 (28\%) hadde CD38-positiv kronisk lymfatisk leukemi og $152(72 \%)$ CD38-negativ.

\section{Molekylærgenetikk}

Identifikasjon av hvilket gen som kodet for den variable delen av immunglobulinets tunge kjede hos KLL-cellene (foretrukket $\mathrm{V}_{\mathrm{H}}$-gen) og bestemmelse av $\mathrm{V}_{\mathrm{H}}$-genets mutasjonsstatus var mulig hos 199 pasienter $(84 \%) .138$ pasienter $(69 \%)$ hadde mutert $\mathrm{V}_{\mathrm{H}^{-}}$-gen og $61(31 \%)$ umutert $\mathrm{V}_{\mathrm{H}^{-} \text {-gen. Hos }}$ 18 pasienter $(9 \%)$ ble det identifisert to $\mathrm{V}_{\mathrm{H}^{-}}$ gener, det vil si de hadde såkalt biallelisk kronisk lymfatisk leukemi - hos 11 var ett (tre pasienter) eller begge (åtte pasienter) $\mathrm{V}_{\mathrm{H}^{-}}$-genene umutert og hos sju var begge $\mathrm{V}_{\mathrm{H}^{-}}$ gener mutert.

Ved kronisk lymfatisk leukemi forekommer noen $\mathrm{V}_{\mathrm{H}}$-gener hyppigere enn andre, og vi fant særlig hyppig ( $>10$ pasienter) bruk av følgende gener: $\mathrm{V}_{\mathrm{H}} 1-69, \mathrm{~V}_{\mathrm{H}} 3-7, \mathrm{~V}_{\mathrm{H}} 3-23$, $\mathrm{V}_{\mathrm{H}} 3-30$ og $\mathrm{V}_{\mathrm{H}} 4-34$.

\section{Ramme 1}

$$
\begin{aligned}
& \text { Median overlevelse fra diagnose- } \\
& \text { tidspunktet ved ulike biologiske } \\
& \text { markører (4-7) } \\
& \text { — Umutert } \mathrm{V}_{\mathrm{H}} \text {-gen - } 95 \text { måneder } \\
& \text { - } \text { Mutert } \mathrm{V}_{\mathrm{H}} \text {-gen - } 293 \text { måneder } \\
& \text { - del(17p13) - } 32 \text { måneder } \\
& \text { - del(11q22) - } 79 \text { måneder } \\
& \text { - Trisomi 12-114 måneder } \\
& \text { - Ingen cytogenetiske avvik - } 111 \text { måneder } \\
& \text { - del(13q14) - } 133 \text { måneder } \\
& \text { - CD38-positivitet - } 120 \text { måneder } \\
& \text { - CD38-negativitet - lik alderstilpasset } \\
& \text { normalbefolkning }
\end{aligned}
$$

Der $\mathrm{V}_{\mathrm{H}} 3-21$ er det foretrukne $\mathrm{V}_{\mathrm{H}}$-genet, er prognosen dårlig - uavhengig av dette $\mathrm{V}_{\mathrm{H}}$-genets mutasjonsstatus (14). Vi fant at $\mathrm{V}_{\mathrm{H}} 3-21$ var det foretrukne $\mathrm{IgV}_{\mathrm{H}}$-genet hos åtte pasienter $(4 \%)$ - det var mutert hos to og umutert hos seks.

\section{Cytogenetikk}

Cytogenetisk undersøkelse med FISH var vellykket hos 112 pasienter. Hos én pasient ble karyotypen fastslått ved G-banding alene. Hos 36 pasienter (32\%) ble det ikke påvist cytogenetiske aberrasjoner, mens dette ble påvist hos 77 (68\%) (tab 2). Karyotypering med G-banding ble utført hos 25 pasienter og avdekket $\mathrm{t}(14 ; 18)(\mathrm{q} 32 ; \mathrm{q} 21)$ hos tre, $\mathrm{t}(11 ; 14)(\mathrm{q} 13 ; \mathrm{q} 32)$ hos én og del(14q22) hos én.

Pasienten med $\mathrm{t}(11 ; 14)(\mathrm{q} 13 ; \mathrm{q} 32)$ hadde både kronisk lymfatisk leukemi og mantelcellelymfom, med omtrent like store cellepopulasjoner vurdert ved væskestrømscytometrisk undersøkelse av beinmargen. Det er overveiende sannsynlig at translokasjonen var knyttet til mantelcellelymfomet fordi denne translokasjonen er karakteristisk for dette lymfomet.

Hos 13 pasienter (12\%) var karyotypen karakterisert ved mer enn én aberrasjon. Tre pasienter fikk påvist $\mathrm{t}(14 ; 18)(\mathrm{q} 32 ; \mathrm{q} 21)$, som er karakteristisk for follikulært lymfom. Ingen av disse tre hadde lymfeknutesvulst av betydning, og tumorcellene hadde hos alle tre

\begin{tabular}{lccc} 
Tabell 1 & Stadieinndeling av kronisk lymfatisk leukemi etter Binet (9) & \\
\hline Stadium & $\begin{array}{c}\text { Involverte lymfoide } \\
\text { organer }^{1}\end{array}$ & $\begin{array}{c}\text { Hemoglobin } \\
(\mathbf{g} / 100 \mathrm{ml})\end{array}$ & Trombocytter (.10\%) \\
\hline A & $<3$ & $\geq 10$ & $\geq 100$ \\
B & $>3$ & $\geq 10$ & $\geq 100$ \\
C & Uten betydning & $<10^{2}$ & $<100^{2}$
\end{tabular}

${ }^{1}$ Fem aktuelle lymfoide organer - lymfeknuter på hals, lymfeknuter i aksillene, lymfeknuter i lyskene milt og lever

Ett eller begge avvik til stede 
Tabell 2 Samvariasjon mellom klinisk stadium, $V_{H^{-}}$gen, immunfenotype og cytogenetiske avvik ved kronisk lymfatisk leukemi

\begin{tabular}{|c|c|c|c|c|}
\hline & $\begin{array}{l}\text { Pasienter } \\
\text { Antall (\%) }\end{array}$ & $\begin{array}{c}\mathrm{V}_{\mathrm{H}} \text {-gen mutert } \\
\text { Antall }(\%)\end{array}$ & $\begin{array}{c}\mathrm{V}_{\mathrm{H}} \text {-gen umutert } \\
\text { Antall }(\%)\end{array}$ & $\begin{array}{l}\text { Ikke data } \\
\text { Antall (\%) }\end{array}$ \\
\hline Stadieinndeling & 222 & & & \\
\hline Binet A & $178(80)$ & $120(67)$ & $28(16)$ & $30(17)$ \\
\hline Binet B & $26(12)$ & 7 (27) & $16(62)$ & $3(11)$ \\
\hline Binet C & $18(8)$ & $5(28)$ & $12(67)$ & $1(6)$ \\
\hline Immunfenotype & 211 & & & \\
\hline CD38-positiv & $59(28)$ & 18 (31) & $34(58)$ & $7(12)$ \\
\hline CD38-negativ & $152(72)$ & 109 (72) & 19 (13) & $23(15)$ \\
\hline FISH-analyse ${ }^{1}$ & 112 & & & \\
\hline Ingen aberrasjoner & 36 (32) & $22(61)$ & 7 (19) & 7 (19) \\
\hline $\operatorname{del}(13 q 14)$ & $53(47)$ & $35(66)$ & $13(25)$ & $2(4)$ \\
\hline Trisomi 12 & $15(13)$ & 5 (33) & 8 (53) & $2(14)$ \\
\hline del(11q22) & $11(10)$ & $4(36)$ & $7(64)$ & 0 \\
\hline del(17p13) & $8(7)$ & $3(38)$ & $3(38)$ & $2(25)$ \\
\hline Karyotypering & 4 & & & \\
\hline $\mathrm{t}(14 ; 18)(q 32 ; q 21)$ & 3 & $2(67)$ & 1 (33) & \\
\hline $\mathrm{t}(11 ; 14)(q 13 ; q 23)$ & 1 & & 1 & \\
\hline del(14q22) & 1 & & & 1 \\
\hline
\end{tabular}

Tabell 3 Mutasjonsstatus hos $\mathrm{V}_{\mathrm{H}}$-gener som forekommer hyppig hos pasienter med kronisk lymfatisk leukemi

\begin{tabular}{|lccc}
\hline Foretrukket $\mathrm{V}_{\mathrm{H}^{-}}$-gen & Antall pasienter & Mutert (\%) & Umutert $(\%)$ \\
\hline $\mathrm{V}_{\mathrm{H}} 1-69$ & 18 & 28 & 72 \\
\hline $\mathrm{V}_{\mathrm{H}} 3-7$ & 20 & 90 & 10 \\
$\mathrm{~V}_{\mathrm{H}} 3-23$ & 16 & 94 & 6 \\
\hline $\mathrm{V}_{\mathrm{H}} 3-30$ & 20 & 65 & 35 \\
$\mathrm{~V}_{\mathrm{H}} 4-34$ & 25 & 80 & 20 \\
\hline
\end{tabular}

karakteristisk KLL-immunfenotype (KLLskår 5) og andre cytogenetiske aberrasjoner som ses hyppig ved kronisk lymfatisk leukemi og ikke ved follikulært lymfom.

\section{Samvariasjon mellom}

de ulike biologiske markørene

Materialet viste entydig at de ulike biologiske markørene samvarierer, men det er ikke slik at én markør kan benyttes som surrogatmarkør for én eller flere av de andre. Hos pasienter i Binets stadium A var det foretrukne $\mathrm{V}_{\mathrm{H}^{-}}$-gen mutert hos flertallet, mens det motsatte var tilfellet hos pasienter i Binets stadium B og stadium C $(\mathrm{p}<0,001)$. CD38-positiv kronisk lymfatisk leukemi var assosiert med umutert og CD38-negativ sykdom med mutert $\mathrm{V}_{\mathrm{H}}$-gen $(\mathrm{p}<0,001)$.

Ved cytogenetiske forandringer som er assosiert med god prognose, var det foretrukne $\mathrm{V}_{\mathrm{H}^{-}}$-gen oftest mutert. Det motsatte var tilfellet ved del(11q22), som er forbundet med dårlig prognose. Dette er oppsummert i tabell 2 . Tabell 3 viser at det ikke var tilfeldig om $\mathrm{V}_{\mathrm{H}^{-}}$genet er mutert eller ikke ved ulik $\mathrm{V}_{\mathrm{H}^{-}}$-gen bruk. $\mathrm{V}_{\mathrm{H}} 1-69$ forekom disse undersøkelsene hos de eldste fordi resultatet ikke ville ha konsekvenser for valg av behandling.

Mangelfull inklusjon av overveiende eldre pasienter har liten betydning for våre beregninger av den relative fordelingen av prognostiske faktorer i pasientpopulasjonen fordi disse faktorene ikke viser ulik fordeling $\mathrm{i}$ ulike aldersgrupper. Derimot er det en klar kjønnsforskjell - høyrisikofaktorer ses hyppigere hos menn enn hos kvinner (4-6). Vår studie må likevel kunne sies å være populasjonsbasert og representativ, men den er ikke uselektert. Seleksjonen synes i stor grad å ligge hos legene fordi noen geografiske områder ikke er representert i studien $i$ tråd med en tidligere studie (1). Beregningene av insidens og kjønnsfordeling var basert på lovpålagte meldinger til Kreftregisteret og ble derfor gjort $\mathrm{i}$ et uselektert materiale.

I de første studiene som beskrev det foretrukne $\mathrm{V}_{\mathrm{H}^{-}}$-genets mutasjonsstatus ved kronisk lymfatisk leukemi, var det tilnærmet lik fordeling av pasienter med mutert og pasienter med umutert $\mathrm{V}_{\mathrm{H}^{-}}$-gen $(4,5)$. Vi fant, derimot, at $69 \%$ av pasientene hadde mutert $\mathrm{V}_{\mathrm{H}^{-}}$ gen og $31 \%$ umutert. Dette samsvarer med nylig publiserte populasjonsbaserte studier fra Europa og USA $(18,19)$, noe som skulle tilsi at vår studie er representativ. De første rapportene kom fra spesialiserte sykehusavdelinger, mens vår studie og de nyere internasjonale studiene er populasjonsbaserte og dermed favner en pasientpopulasjon som i større grad inkluderer dem med indolent sykdom, hvor vi ville forvente at kronisk lymfatisk leukemi med mutert $\mathrm{V}_{\mathrm{H}}$-gen dominerer.

Allerede i 1988 beskrev Kipps og medarbeidere at KLL-celler benyttet et begrenset repertoar av $\mathrm{V}_{\mathrm{H}}$-gener (20). Disse observasjonene er bekreftet i flere studier, og en metaanalyse viser at de foretrukne $\mathrm{V}_{\mathrm{H}^{-}}$-genfamiliene ved kronisk lymfatisk leukemi skiller seg fra repertoaret hos normale B-lymfocytter $(21,22)$. Vår studie føyer seg inn i rekken.

Kronisk lymfatisk leukemi hvor begge IgH-gener er rearrangert er velkjent. Det benevnes biallelisk kronisk lymfatisk leukemi, til forskjell fra biklonal kronisk lymfatisk leukemi, hvor to ulike KLL-kloner forekommer side om side $(23,24)$. Hvor hyppig biallelisk kronisk lymfatisk leukemi er, har ikke vært omtalt tidligere. I vårt materiale hadde $9 \%$ av pasientene biallelisk kronisk lymfatisk leukemi, og ett eller begge de foretrukne $\mathrm{V}_{\mathrm{H}}$-genene var umutert hos flertallet $(61 \%)$.

Vi fant, i likhet med andre, at KLL-cellene hos en drøy firedel av pasientene uttrykte CD38 på celleoverflaten (19). CD38positiv kronisk lymfatisk leukemi benyttet som oftest et umutert $\mathrm{V}_{\mathrm{H}^{-}}$-gen $(58 \%)$, men CD38-ekspresjonen kan på ingen måte benyttes som surrogatmarkør for $\mathrm{V}_{\mathrm{H}}$-genets mutasjonsstatus (7).

I sykehusmaterialer er det rapportert at ca. $80 \%$ av pasientene har genetiske aberrasjoner i KLL-cellene når de blir undersøkt for $\operatorname{del}(13 q 14), \operatorname{del}(11 q 22)$, del(17p13) eller tri- 
somi 12 ved hjelp av FISH-analyse, mens ca. $20 \%$ ikke har cytogenetiske avvik (6). I vårt materiale er andelen uten cytogenetiske aberrasjoner noe høyere $(33 \%)$, men den innbyrdes fordelingen av de ulike cytogenetiske aberrasjonene er slik som rapportert av andre (tab 2). Hos $12 \%$ av pasientene fant vi flere cytogenetiske aberrasjoner. Andre har vist at prognosen hos disse pasientene bestemmes av den aberrasjonen som er assosiert med dårligst prognose (6).

Det kan være flere forklaringer på den noe høyere andelen uten cytogenetiske aberrasjoner $\mathrm{i}$ vårt materiale. Metodologisk forhold som resulterte $i$ at avvik ikke ble oppdaget, er én mulighet, men hvis dette skulle være forklaringen, ville vi forventet avvik også i den innbyrdes fordelingen av cytogenetiske aberrasjoner i forhold til andre materialer. De aktuelle cytogenetiske avvikene regnes ikke som primære patogenetiske hendelser ved kronisk lymfatisk leukemi, de kommer til underveis. Det er derfor nærliggende å forvente en høyere andel pasienter uten cytogenetiske aberrasjoner i et populasjonsbasert materiale enn i materialer fra spesialavdelinger. En begrensning ved vårt materiale er at cytogenetisk undersøkelse ble utført hos en relativt lav andel av pasientene ( $48 \%)$.

De biologiske markørene har stor prognostisk utsagnskraft, og de kan være til stor hjelp ved informasjon til den enkelte pasient om prognosen. Dette er spesielt viktig fordi hoveddelen av pasientene blir diagnostisert i en asymptomatisk fase av sykdommen da behandling ikke er indisert. Foreløpig er det ikke aktuelt å velge behandling på basis av biologiske markører - med ett unntak: Ved kronisk lymfatisk leukemi karakterisert ved $\operatorname{del}(17 \mathrm{p} 13)$ er det enighet om at pasientene bør få behandling som er uavhengig av p53signalveien (genet TP53 ligger i kromosombånd $17 \mathrm{p} 13$ ) for å være effektiv (25). Immunkjemoterapi (rituximab, fludarabin og cyklofosfamid) anses i dag som den beste førstelinjebehandlingen ved kronisk lymfatisk leukemi for dem som tåler aggressiv terapi (70 år eller yngre og ingen komorbiditet). Effekten av immunkjemoterapi er spesielt god ved umutert $\mathrm{V}_{\mathrm{H}}$-gen, del(13q14) og del(11q23) (26).

\section{Geir E. Tjønnfjord (f. 1953)}

er avdelingsleder for Avdeling for blodsykdommer, Oslo universitetssykehus, og professor i hematologi ved Institutt for klinisk medisin. Universitetet i Oslo. Han er spesialist i indremedisin og blodsykdommer.

Forfatter har fylt ut ICMJE-skjemaet og oppgir ingen interessekonflikter.

\section{Bernt E. Ly (f. 1936)}

er tidligere avdelingsoverlege ved Avdeling for hematologi, Aker universitetssykehus. Han er spesialist $\mathrm{i}$ indremedisin og blodsykdommer. Forfatter har fylt ut ICMJE-skjemaet og oppgir ingen interessekonflikter.
Tom Børge Johannesen (f. 1965)

er nestleder ved Avdeling for klinisk forskning. Kreftregisteret. Han er spesialist i onkologi. Forfatter har fylt ut ICMJE-skjemaet og oppgir ingen interessekonflikter.

\section{Anne Tierens (f. 1960)}

er overlege ved Avdeling for patologi, Oslo universitetssykehus. Hun er spesialist i patologi med spesialkompetanse i væskestrømscytometri.

Forfatter har fylt ut ICMJE-skjemaet og oppgir ingen interessekonflikter.

\section{Klaus Beiske (f. 1949)}

er overlege ved Avdeling for patologi, Oslo universitetssykehus. Han er spesialist i patologi med spesialkompetanse i FISH-analyser Forfatter har fylt ut ICMJE-skjemaet og oppgir ingen interessekonflikter.

\section{Sverre Heim (f. 1951)}

er avdelingsleder ved Laboratorium for kreftgenetikk, Oslo universitetssykehus, og professor i medisinsk genetikk ved Institutt for klinisk medisin, Universitetet i Oslo. Han er spesialist i kreftgenetikk.

Forfatter har fylt ut ICMJE-skjemaet og oppgir ingen interessekonflikter.

\section{Viggo Jønsson (f. 1948)}

er overlege ved Avdeling for blodsykdommer, Oslo universitetssykehus og professor i hematologi ved Institutt for klinisk medisin, Universitetet i Oslo. Han er spesialist i indremedisin og blodsykdommer.

Forfatter har fylt ut ICMJE-skjemaet og oppgir ingen interessekonflikter.

Artikkelen er skrevet på vegne av norsk KLLstudiegruppe.

\section{Litteratur}

1. Ly B, Hammerstrøm J, Bergheim J et al. Kronisk lymfatisk leukemi. En populasjonsbasert unders $\varnothing$ kelse av symptomer, funn, komplikasjoner og behandlingsvalg. Tidsskr Nor Lægeforen 1998; 118: 228-32.

2. Rozman C, Montserrat E. Chronic lymphocytic leukemia. N Engl J Med 1995; 333: 1052-7.

3. Del Giudice I, Chiaretti S, Tavolaro S et al. Spontaneous regression of chronic lymphocytic leukemia: clinical and biologic features of 9 cases. Blood 2009; 114: 638-46.

4. Damle RN, Wasil T, Fais F et al. Ig V gene mutation status and CD38 expression as novel prognostic indicators in chronic lymphocytic leukemia. Blood 1999: 94: 1840-7

5. Hamblin TJ, Davis Z, Gardiner A et al. Unmutated $\lg V(H)$ genes are associated with a more aggressive form of chronic lymphocytic leukemia. Blood 1999: 94: 1848-54

6. Döhner H, Stilgenbauer S, Benner A et al. Genomic aberrations and survival in chronic lymphocytic leukemia. N Engl J Med 2000; 343: 1910-6.

7. Hamblin TJ, Orchard JA, Ibbotson RE et al. CD38 expression and immunoglobulin variable region mutations are independent prognostic variables in chronic lymphocytic leukemia, but CD38 expression may vary during the course of the disease. Blood 2002. 99: 1023-9.

8. Hallek M, Cheson BD, Catovsky D et al. Guidelines for the diagnosis and treatment of chronic lymphocytic leukemia: a report from the International Workshop on Chronic Lymphocytic Leukemia updating the National Cancer Institute-Working Group 1996 guidelines. Blood 2008; 111: 5446-56.
9. Binet JL, Auquier A, Dighiero $G$ et al. A new prognostic classification of chronic lymphocytic leukemia derived from a multivariate survival analysis. Cancer 1981; 48: 198-206.

10. Rothe G, Schmitz G. Consensus protocol for the flow cytometric immunophenotyping of hematopoietic malignancies. Working group on flow cytometry and image analysis. Leukemia 1996; 10: 877-95.

11. van Dongen JJ, Langerak AW, Brüggemann M et al. Design and standardization of PCR primers and protocols for detection of clonal immunoglobulin and T-cell receptor gene recombinations in suspect lymphoproliferations: report of the BIOMED-2 Concerted Action BMH4-CT98-3936. Leukemia 2003; 17: 2257-317.

12. Verhagen OJ, Willemse MJ, Breunis WB et al. Application of germline IGH probes in real-time quantitative PCR for the detection of minimal residual disease in acute lymphoblastic leukemia. Leukemia 2000; 14: 1426-35.

13. Matutes E, Owusu-Ankomah K, Morilla R et al. The immunological profile of B-cell disorders and proposal of a scoring system for the diagnosis of CLL. Leukemia 1994; 8: 1640-5.

14. Tobin G, Söderberg O, Thunberg $U$ et al. $V(H) 3-21$ gene usage in chronic lymphocytic leukemia characterization of a new subgroup with distinct molecular features and poor survival. Leuk Lymphoma 2004; 45: $221-8$

15. Dores GM, Anderson WF, Curtis RE et al. Chronic lymphocytic leukaemia and small lymphocytic lymphoma: overview of the descriptive epidemiology. Br J Haematol 2007; 139: 809-19.

16. Hansen NE, Karle H, Jensen OM. Trends in the incidence of leukemia in Denmark, 1943-77: an epidemiologic study of 14,000 patients. J Natl Cancer Inst 1983; 71: 697-701.

17. Erlanson $M$, Osterman $B$, Jonsson $\mathrm{H}$ et al. Chronic lymphocytic leukemia: a retrospective study of 122 cases. Eur J Haematol 1994: 52: 108-14.

18. Del Giudice I, Mauro FR, De Propris MS et al. White blood cell count at diagnosis and immunoglobulin variable region gene mutations are independent predictors of treatment-free survival in young patients with stage A chronic lymphocytic leukemia. Haematologica 2011; 96: 626-30.

19. Shanafelt TD, Drake MT, Maurer MJ et al. Vitamin $D$ insufficiency and prognosis in chronic lymphocytic leukemia. Blood 2011: 117: 1492-8.

20. Kipps TJ, Tomhave E, Chen PP et al. Autoantibody associated kappa light chain variable region gene expressed in chronic lymphocytic leukemia with little or no somatic mutation. Implications for etiology and immunotherapy. J Exp Med 1988; 167 $840-52$

21. Chiorazzi N, Rai KR, Ferrarini M. Chronic lymphocytic leukemia. N Engl J Med 2005; 352: 804-15

22. Chiorazzi N, Ferrarini M. Immunoglobulin variable region gene characteristics and surface membrane phenotype define B-CLL subgroups with distinct clinical courses. I: Cheson BD, red. Chronic lymphoid leukemias. New York: Marcel Dekker, 2001: 81-109.

23. Hsi ED, Hoeltge G. Tubbs RR. Biclonal chronic lymphocytic leukemia. Am J Clin Pathol 2000; 113: 798-804

24. Cerny J, Slavickova A, Krepelova A et al. Biallelic lgH rearrangements in patients with indolent lymphoproliferative disorders: molecular and practical implications. J Cell Physiol 2004; 199: 217-26.

25. Gribben JG. How I treat CLL up front. Blood 2010; 115: 187-97.

26. Hallek M. Fischer K, Fingerle-Rowson G et al. Addition of rituximab to fludarabine and cyclo phosphamide in patients with chronic lymphocytic leukaemia: a randomised, open-label, phase 3 trial. Lancet 2010; 376: 1164-74.

Mottatt 29.11. 2011, første revisjon innsendt 9.4 2012, godkjent 5.7. 2012. Medisinsk redaktør Trine B. Haugen. 